\title{
Aspects of the epizootiology of pancreas disease in farmed Atlantic salmon Salmo salar in Ireland
}

\author{
T. Crockford ${ }^{1, *}$, F. D. Menzies ${ }^{2}$, M. F. McLoughlin ${ }^{2}$, S. B. Wheatley ${ }^{1}$, E. A. Goodall ${ }^{3}$ \\ 'The Queen's University of Belfast, Department of Veterinary Sciences, Veterinary Sciences Division, Stoney Road, \\ Belfast BT4 3SD, Northern Ireland, UK \\ ${ }^{2}$ Department of Agriculture for Northern Ireland, Veterinary Sciences Division, Stoney Road, Belfast BT4 3SD, \\ Northern Ireland, UK \\ ${ }^{3}$ Biometrics Division, Agriculture and Food Science Centre, Newforge Lane, Belfast BT9 5PX, Northern Ireland, UK
}

\begin{abstract}
A computerised database containing information on over 17.8 million salmon contained within 49 separate marine populations was used to study the epidemiology of pancreas disease (PD) in Ireland. Of the 43 recorded PD outbreaks, $57 \%$ occurred in the 3 mo period August to October inclusive (17 to $32 \mathrm{wk}$ post-transfer). Analysis of variance of mortality rates during PD outbreaks occurring on 6 marine sites over a 5 yr period showed that mortality rates vary significantly between sites ( $p<$ $0.001)$ but not between years over this time period. The mortality rate during PD outbreaks ranged from 0.1 to $63 \%$. Mortality rates were significantly higher when PD outbreaks occurred earlier in the year $(y=-1.28 \mathrm{x}+59, \mathrm{SE}$ of $b 0.33)$. The mean length of a PD outbreak was $112 \mathrm{~d}(\mathrm{SE}=7.7, \mathrm{n}=37)$. There was no correlation between PD mortality rate and smolt input weight, initial stocking density and transfer mortality.
\end{abstract}

KEY WORDS: Atlantic salmon - Pancreas disease $\cdot$ Epidemiology $\cdot$ Disease management

\section{INTRODUCTION}

The multifactorial nature of many diseases in production animal populations requires that factors associated with the occurrence of specific diseases are best investigated at the population level, rather than at the individual level. Despite the economic growth of Atlantic salmon farming with a concomitant increase in disease and production problems, relatively few epizootiological studies have been initiated into the investigation of disease conditions of farmed Atlantic salmon (Ellis 1987, Jarp et al. 1993, 1994, Wheatley et al. 1995, Crockford et al. 1998, Jarp 1998).

A database was established to facilitate the monitoring of disease and production within the Irish farmed salmon industry during the marine stages of production (Menzies et al. 1996). The use of the system has shown that pancreas disease (PD) has been the most significant factor influencing mortality in Irish farmed

·E-mail: tc1@compuserve.com
Atlantic salmon during their first year at sea (Wheatley et al. 1995). In contrast, vibriosis resulted in a low level of mortality and furunculosis was a relatively minor cause of mortality in Atlantic salmon during their first year at sea in Ireland (Wheatley et al. 1995). Mortality rates of up to $48 \%$ have occurred in farmed Atlantic salmon in their first year at sea on some individual Irish farms (Menzies et al. 1996). This rate is dramatically above the $10 \%$ annual mortality rate which has been generally considered to be an economically acceptable level on individual marine Atlantic salmon farms in Ireland (Bord Iascaigh Mhara 1986).

PD was initially described in Scotland (Munro et al. 1984). The condition is now known to occur in Norway, Scotland and Ireland, which are the major Atlantic salmon farming countries in Europe, as well as on the west coast of USA, and normally affects salmon during their first year at sea (Ferguson et al. 1986, Kent \& Elston 1987, McVicar 1987, Poppe et al. 1989, Murphy et al. 1992). Investigations indicated there was evidence that PD may be caused by a viral-like agent, as the condition had been successfully transmitted to 
healthy salmon by injection of filtered kidney homogenates taken from salmon showing early signs of PD (McVicar 1990, Raynard \& Houghton 1993). Time series analyses of mortality data also suggested that PD may be caused by an infectious agent (Menzies et al. 1996). PD has now been shown to be caused by a toga-like virus, named salmon pancreas disease virus (SPDV) (Nelson et al. 1995, McLoughlin et al. 1996). Clinically, the presenting signs of PD are a rapid decline in feed intake along with a tendency for fish to congregate in the corners of cages close to the surface of the water and with the appearance of white faecal casts (Munro et al. 1984, Ferguson et al. 1986, Murphy et al. 1992). Other aspects on the infectious nature of PD are discussed in detail elsewhere (Houghton 1994, Raynard \& Houghton 1995).

The computerised database was used to study the epizootiology of PD. This paper quantifies prevalence and temporal distribution patterns, and investigates possible associations between other causes of mortality and PD outbreaks in Irish farmed Atlantic salmon during the first year of production at sea.

\section{MATERIALS AND METHODS}

The Irish farmed salmon industry. Ireland produces the third largest quantity of farmed salmon in Europe with an annual tonnage of 15000 worth $£ 45$ million in 1998 (Anonymous 1998). Smolts are normally transferred to the marine sites during March and April, when they weigh 45 to $100 \mathrm{~g}$. Sites are usually stocked with different smolt strains from several different hatchery sources with up to 5 different groups of fish being held on the 1 site. The relatively warmer water temperatures encountered on the west coast of Ireland, where the majority of marine sites are based, encourage rapid growth and hence harvesting tends to occur ahead of the Norwegian and Scottish salmon farms.

Data collection. The data presented relate to over 17.8 million Atlantic salmon smolts that were placed in 11 marine Atlantic salmon farms located on the western coast of Ireland. A total of 509 cages of Atlantic salmon in their first year at sea was included in these data, which covered 49 separate marine site populations (from smolt input to the end of December inclusive) between 1989 and 1994. Production information, including mortality data, was obtained by downloading and standardising data from the various spreadsheet packages used by producers. Information was collected by completion of an annual smolt performance questionnaire and by visits to the participating marine sites. Copies of laboratory reports were obtained during visits and were used to assist in defining disease outbreaks. The methods used in selecting farms for intensive monitoring and the production, disease and environmental variables stored in the computerised information retrieval system are detailed elsewhere (Menzies et al. 1996).

Software and statistical analyses. The salmon farm information retrieval system was configured on the

Table 1. Criteria used to define periods of occurrence of the major disease conditions on sites recorded on the database

\begin{tabular}{|ll|}
\hline Disease & Definition \\
\hline PD & Where: \\
& (1) Clinical signs of PD (includes reduced \\
& feeding rate and/or appearance of faecal \\
& casts and/or behavioural signs of PD) \\
& noticed on site by farm staff at sites with \\
& a history of PD and where PD pathology \\
& was subsequently identified in the stocks \\
& on site during the same year of production \\
& OR \\
& (2) Laboratory reports indicate lesions typ- \\
PD cleared & $\begin{array}{l}\text { Producer stated that feeding, behaviour } \\
\text { and mortality rates returned to normal }\end{array}$ \\
& and no further pancreatic pathology was \\
reported by laboratory & Isolation on culture of Vibrio spp. \\
Fibriosis & Isolation on culture of Aeromonas salmoni- \\
cida
\end{tabular}

Table 2. Definitions of the mortality rates (from smolt input to the end of December inclusive of the first year at sea)

\begin{tabular}{|c|c|}
\hline \multicolumn{2}{|c|}{ Mortality rate Definition } \\
\hline Total & $\begin{array}{l}\text { Mortality as a proportion of total smolt } \\
\text { input }\end{array}$ \\
\hline Disease & $\begin{array}{l}\text { Mortality as a proportion of total smolt } \\
\text { input which occurred during periods of } \\
\text { disease outbreak (PD, vibriosis or furuncu- } \\
\text { Iosis) }\end{array}$ \\
\hline$P D^{a}$ & $\begin{array}{l}\text { Mortality as a proportion of total smolt } \\
\text { input which occurred during periods in } \\
\text { which PD occurred on site }\end{array}$ \\
\hline Vibriosis $^{\mathrm{b}}$ & $\begin{array}{l}\text { Mortality as a proportion of total smolt } \\
\text { input which occurred during periods in } \\
\text { which vibriosis occurred on site }\end{array}$ \\
\hline Transfer $^{c}$ & $\begin{array}{l}\text { Mortality as a proportion of total smolt } \\
\text { input from smolt input to the end of June of } \\
\text { the first year at sea }\end{array}$ \\
\hline \multicolumn{2}{|c|}{$\begin{array}{l}\text { Mortalities during concurrent outbreaks of vibriosis or } \\
\text { furunculosis were excluded }\end{array}$} \\
\hline \multicolumn{2}{|c|}{$\begin{array}{l}{ }^{b} \text { Mortalities during concurrent outbreaks of furunculosis } \\
\text { were excluded and mortalities during concurrent } \\
\text { outbreaks of PD were included }\end{array}$} \\
\hline \multicolumn{2}{|c|}{$\begin{array}{l}\text { "Mortalities during concurrent outbreaks of PD, vibriosis } \\
\text { or furunculosis were excluded }\end{array}$} \\
\hline
\end{tabular}


relational database management system ORACLE (ORACLE Corporation, CA, USA). SPSS-X (SPSS, Chicago, IL, USA) was the main software package used for statistical analysis of the data. Latterly, MS ACCESS (Microsoft Corporation, Redmond, WA, USA) has been used to query the data.

Percentage mortality was used as the measure of production due to the inability to assess biomass accurately on the majority of the monitored sites. Mortality data were subjected to the arcsine root transformation for analysis of variance and are marked 'AS' within the text so that this can be readily identified (Walters 1979). Mortality rates were compared between sites and years using analysis of variance. When analysis of variance resulted in a significant $F$-test value, the Least Significant Differences (LSD) test was used to compare sites.

Standard linear regression and correlation techniques were used to examine the data (Draper $\&$ Smith 1966). Where a statistically significant correlation was shown, a dependency relationship was postulated and a regression analysis was performed. In each analysis, mortality was the dependent variable and the hypothesized factor was the independent variable.

Definitions of periods of disease outbreak. Clinical and pathological signs of the major disease conditions used to define the criteria for inclusion of the disease occurrence into the database were defined (Table 1). This definition ensured that all disease data were standardised between sites. Clinical signs alone were not accepted as a diagnosis of PD and histological examination was required to confirm an outbreak of PD.

Definitions of mortality rates. Mortality rates (from smolt input to the end of December inclusive of the first year at sea) were defined as given in Table 2 . The definitions used for disease occurrence variables are described in Table 3.
Table 3. Definitions of disease occurrence variables

\begin{tabular}{|ll|}
\hline $\begin{array}{l}\text { Disease occur- } \\
\text { rence variable }\end{array}$ & Definition \\
\hline PD prevalence & $\begin{array}{l}\text { Number of sites suffering PD as a pro- } \\
\text { portion of sites monitored each year }\end{array}$ \\
PD start & $\begin{array}{l}\text { Sites categorised as having PD if: } \\
\text { (1) Producer stated that PD was ob- } \\
\text { served and where PD pathology was } \\
\text { subsequently identified in the stocks on } \\
\text { site during the same year of production. } \\
\text { Producers based their observations of } \\
\text { PD on a combination of feeding levels } \\
\text { and behavioural signs } \\
\text { OR } \\
\text { (2) If pathology reports indicated lesions } \\
\text { typical of PD in fish sampled on site } \\
\text { without clinical signs having been ob- } \\
\text { served by the producer } \\
\text { From PD start date to when producer } \\
\text { said that feeding, behaviour and mortal- } \\
\text { ity levels had returned to normal and no } \\
\text { further pancreatic pathology was } \\
\text { reported }\end{array}$ \\
Timing of smolt & $\begin{array}{l}\text { Date of smolt transfer to sea } \\
\text { input }\end{array}$ \\
&
\end{tabular}

\section{RESULTS}

The average total mortality from input to the end of December in the years monitored (1989 to 1994) was 23.9\%. Total mortalities between 1989 and 1994 decreased $(y=-4.3 x+8594$, SE of $b 1.49, t=2.88, \mathrm{p}<$ 0.01 ) with the average mortality during $1993 / 1994$ being only $13.5 \%$ (Fig. 1 ).

There was also a significant downward trend in the mortalities due to disease generally $(y=-3.7 x+7395$, $\mathrm{SE}$ of $b 1.46, t=2.538, \mathrm{p}<0.05)$, mortalities due to PD
Fig. 1. Salmo salar. Mean annual mortality rates for monitored marine sites between 1989 and 1994. Mortality rates due to pancreas disease (PD), vibriosis and transfer losses are illustrated

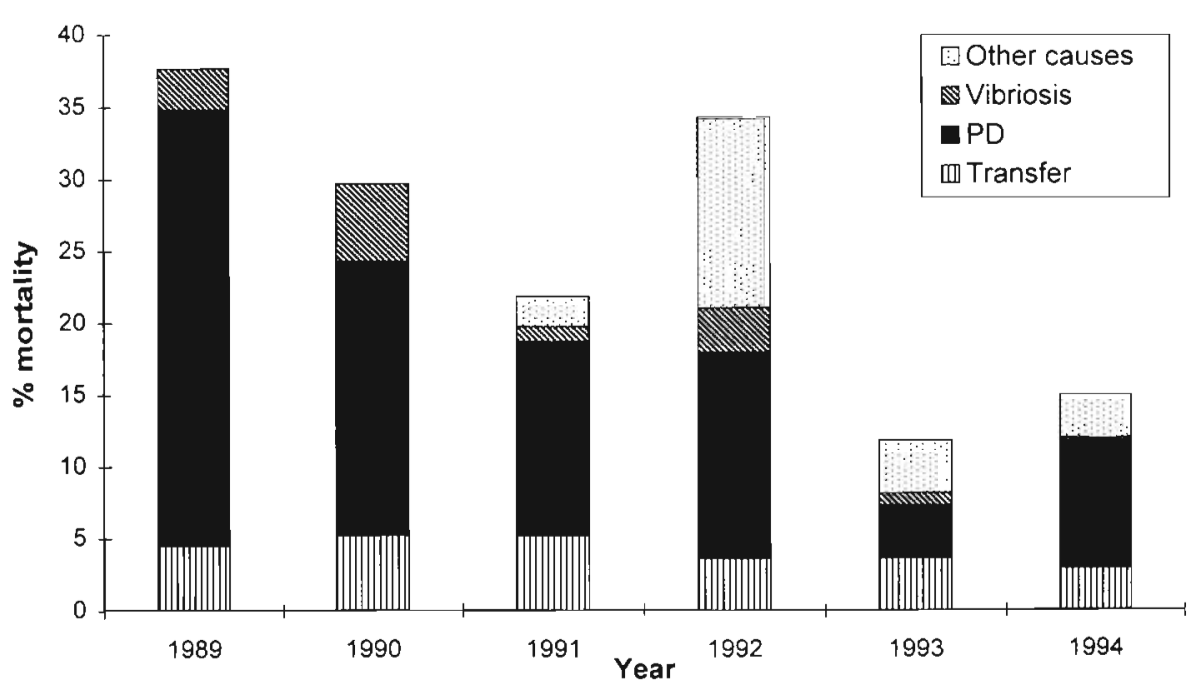


Table 4. Annual statistics on monitored marine sites and the prevalence of pancreas disease on these sites between 1989 and 1994 na = data for total Irish smolts put to sea not available

\begin{tabular}{|lcccc|}
\hline $\begin{array}{l}\text { Production } \\
\text { Year }\end{array}$ & $\begin{array}{c}\text { \% of monitored } \\
\text { sites with a PD } \\
\text { outbreak }\end{array}$ & $\begin{array}{c}\% \text { of total Irish } \\
\text { smolts being } \\
\text { monitored }\end{array}$ & $\begin{array}{c}\text { No. of } \\
\text { cages being } \\
\text { monitored }\end{array}$ & $\begin{array}{c}\text { No. of marine } \\
\text { sites being } \\
\text { monitored }\end{array}$ \\
\hline 1989 & 100 & na & 22 & 3 \\
1990 & 100 & na & 99 & 11 \\
1991 & 90 & 44 & 116 & 10 \\
1992 & 100 & 48 & 85 & 8 \\
1993 & 87 & 35 & 89 & 8 \\
1994 & 70 & 50 & 98 & 10 \\
\hline
\end{tabular}

Table 5. Annual percentage PD mortality rates from 6 sites, 1990 to 1994 (arcsine root transformed data). General mean (SE) of untransformed data = $12.13(3.21$ ). General mean (SE) of arcsine root transformed data $=0.286$ (0.047). na = data not available

\begin{tabular}{|c|c|c|c|c|c|c|c|}
\hline Site & 1990 & 1991 & 1992 & 1993 & 1994 & Mean & $\mathrm{SE}$ \\
\hline 1 & $\begin{array}{c}9.51 \\
(0.314)\end{array}$ & $\begin{array}{c}2.31 \\
(0.152)\end{array}$ & $\begin{array}{c}5.00 \\
(0.226)\end{array}$ & na & $\begin{array}{c}0.91 \\
(0.095)\end{array}$ & $\begin{array}{c}4.43 \\
(0.197)\end{array}$ & $\begin{array}{c}1.89 \\
(0.047)\end{array}$ \\
\hline 2 & $\begin{array}{c}4.19 \\
(0.206)\end{array}$ & $\begin{array}{c}8.66 \\
(0.299)\end{array}$ & $\begin{array}{c}0.27 \\
\{0.052\}\end{array}$ & $\begin{array}{c}1.27 \\
(0.113)\end{array}$ & $\begin{array}{c}0.89 \\
(0.094)\end{array}$ & $\begin{array}{c}3.06 \\
(0.153)\end{array}$ & $\begin{array}{c}1.56 \\
(0.044)\end{array}$ \\
\hline 3 & $\begin{array}{c}12.59 \\
(0.363)\end{array}$ & $\begin{array}{c}3.66 \\
(0.192)\end{array}$ & $\begin{array}{c}0.04 \\
(0.020)\end{array}$ & $\begin{array}{c}13.42 \\
(0.375)\end{array}$ & $\begin{array}{c}1.06 \\
(0.103)\end{array}$ & $\begin{array}{c}6.15 \\
(0.211)\end{array}$ & $\begin{array}{c}2.86 \\
(0.070)\end{array}$ \\
\hline 4 & $\begin{array}{c}30.98 \\
(0.590)\end{array}$ & $\begin{array}{c}42.46 \\
(0.710)\end{array}$ & $\begin{array}{l}29.88 \\
(0.578)\end{array}$ & na & $\begin{array}{c}63.20 \\
(0.919)\end{array}$ & $\begin{array}{c}41.63 \\
(0.699)\end{array}$ & $\begin{array}{c}7.73 \\
(0.079)\end{array}$ \\
\hline 5 & $\begin{array}{c}0.30 \\
(0.055)\end{array}$ & $\begin{array}{c}4.78 \\
(0.220)\end{array}$ & $\begin{array}{c}1.99 \\
(0.141)\end{array}$ & $\begin{array}{c}0.19 \\
(0.043)\end{array}$ & $\begin{array}{c}1.32 \\
(0.115)\end{array}$ & $\begin{array}{c}1.72 \\
(0.115)\end{array}$ & $\begin{array}{c}0.84 \\
(0.032)\end{array}$ \\
\hline 6 & $\begin{array}{c}14.36 \\
(0.389)\end{array}$ & $\begin{array}{c}38.62 \\
(0.671)\end{array}$ & $\begin{array}{c}35.45 \\
(0.638)\end{array}$ & $\begin{array}{c}0.12 \\
(0.035)\end{array}$ & na & $\begin{array}{c}22.14 \\
(0.433)\end{array}$ & $\begin{array}{c}9.10 \\
(0.147)\end{array}$ \\
\hline Mean & $\begin{array}{c}11.99 \\
(0.319)\end{array}$ & $\begin{array}{l}16.75 \\
0.374)\end{array}$ & $\begin{array}{c}12.11 \\
0.276)\end{array}$ & $\begin{array}{c}3.75 \\
0.142)\end{array}$ & $\begin{array}{c}13.48 \\
(0.266)\end{array}$ & & \\
\hline SE & $\begin{array}{c}4.36 \\
(0.074)\end{array}$ & $\begin{array}{c}7.59 \\
(0.102)\end{array}$ & $\begin{array}{c}6.58 \\
(0.109)\end{array}$ & $\begin{array}{c}3.23 \\
(0.080)\end{array}$ & $\begin{array}{c}12.43 \\
(0.163)\end{array}$ & & \\
\hline
\end{tabular}

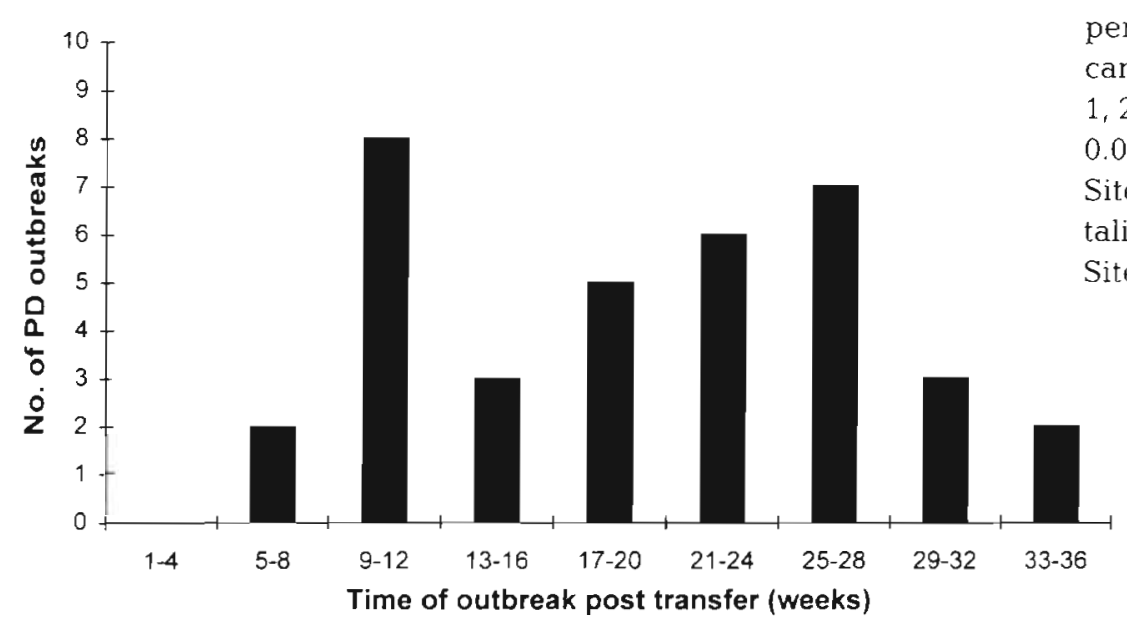

Fig. 2. Frequency of outbreaks of pancreas disease (PD) in relation to the time between smolt input and the start of an outbreak $(y=-4.1 x+8263$, SE of $b 1.52, t=2.723$, $\mathrm{p}<0.01)$ and transfer losses $(y=-0.76 x+$ 1525, SE of $b 0.358, t=2.13, \mathrm{p}<0.05)$ during 1989 to 1994 (Fig. 1). There was no significant trend in vibriosis mortalities between 1989 and 1994. The other causes of mortality illustrated in Fig. 1 were mainly salmon mortalities where no specific disease could be attributed and also other minor causes of mortality such as algal blooms and seal/whale attacks. A large proportion of the mortalities categorised as other causes in 1992 was due to an algal bloom.

Annual PD outbreaks were recorded on $70 \%$ or more of the monitored sites between 1989 and 1994 (Table 4). During the latter years, the number of smolts being monitored using this system represented between 35 and $50 \%$ of the total smolt input into Irish marine sites (Table 4).

Between 1989 and 1994 there were 43 outbreaks of PD reported from the monitored sites, with $57 \%$ of these outbreaks starting within the 3 mo period August to October inclusive. A similar pattern was seen where the number of PD outbreaks was compared to weeks post-transfer to sea water, $55 \%$ of these outbreaks starting within the period 17 to $32 \mathrm{wk}$ posttransfer (Fig. 2). The mean date of transfer was 8 April (range 1 March to 16 May: SE $0.65)$.

Analysis of annual mortality rates during outbreaks of PD over 6 sites between 1990 and 1994 showed that mortalities were statistically significantly different between sites $(p<0.001)$ but were not significantly different between years over this 5 yr time period (Table 5). Over the period 1990 to 1994, Site 4 had a significantly higher PD mortality rate than Sites $1,2,3$, and $5(p<0.001$, AS) and Site $6(p<$ 0.05 , AS) (Table 6). Over the same period Site 6 had a significantly higher PD mortality rate than Site $5(p<0.01, A S)$ and Sites $1,2,3$, and 4 ( $p<0.05$, AS) (Table 6). 
Table 6. Least significant differences comparison of the differences in annual percentage PD mortality from 6 sites, 1990 to 1994. The (mean) value is the mean annual percentage PD mortality from that site between 1990 and 1994. NS = not statistically significant $(p>0.05)$

\begin{tabular}{|cccccccc|}
\hline \multirow{2}{*}{$\begin{array}{c}\text { Site no. } \\
\text { (mean): }\end{array}$} & 1 & 2 & 3 & 4 & 5 & 6 \\
\hline 1 & $(4.43)$ & $(3.06)$ & $(6.15)$ & $(41.63)$ & $(1.72)$ & $(22.14)$ \\
\hline 2 & - & NS & NS & $p<0.001$ & NS & $p<0.05$ \\
3 & - & - & NS & $p<0.001$ & NS & $p<0.05$ \\
4 & - & - & - & $p<0.001$ & NS & $p<0.05$ \\
5 & - & - & - & - & $p<0.001$ & $p<0.05$ \\
6 & - & - & - & - & - & $p<0.01$ \\
& - & - & - & - & - & - \\
\hline
\end{tabular}

A very highly statistically significant correlation was obtained between the date when a PD outbreak occurred and the percentage mortality during an outbreak ( $r=0.53$ ). The mortality rates were higher when PD outbreak occurred earlier in the year $(y=-1.28 x+$ 59, SE of $b 0.33, t=3.87, \mathrm{p}<0.001)$. Fig. 3 shows the relationship between the week of the year and the percentage mortality from PD outbreaks over that time period. A similar correlation was found between the time from smolt input to the outbreak of PD and the percentage mortality during the outbreak $(y=-0.15 x+$ $34.3, \mathrm{SE}$ of $b 0.051, t=2.92, \mathrm{p}<0.01$ ).

The mean length of a PD outbreak between 1989 and 1994 was $112 \mathrm{~d}(\mathrm{SE}=7.7, \mathrm{n}=37$, Table 7$)$. No statistically significant difference was observed between years for the duration of PD outbreaks.

There was a highly statistically significant correlation between PD mortality rate and the duration of the outbreak of PD $(y=1.36 x-4.37$, SE of $b 0.354, t=3.849$, $p<0.001)$. The duration of PD outbreaks $(y)$ tended to be longer when they occurred earlier in the year $(x)$ $(y=-0.60 x+35.84$, SE of $b 0.138, t=4.35, p<0.001)$.
Table 7. Annual variation in the duration of $\mathrm{PD}$ in days

\begin{tabular}{|lccc|}
\hline Year & $\begin{array}{c}\text { Mean duration } \\
\text { of PD outbreaks (d) }\end{array}$ & SE & $\begin{array}{c}\text { No. of } \\
\text { outbreaks }\end{array}$ \\
\hline 1989 & 149.3 & 24.7 & 3 \\
1990 & 126.7 & 17.3 & 9 \\
1991 & 118.8 & 17.8 & 9 \\
1992 & 79.0 & 15.3 & 7 \\
1993 & 94.5 & 18.4 & 4 \\
1994 & 112.0 & 6.3 & 5 \\
Overall & 112 & 7.7 & 37 \\
\hline
\end{tabular}

There was no correlation between PD mortality and smolt input weight, initial stocking density or transfer mortality.

Data were analysed by geographical region (i.e. north, south, or mid-west coast of Ireland). No correlation was found between the overall geographical location of sites and the duration of PD outbreak nor date of onset of such occurrences.

A correlation was demonstrated between PD mortality and mortality due to vibriosis $(y=2.13 x+4385$, SE of $b 0.55, t=3.9, \mathrm{p}<0.001$ ), but any association was deemed to be spurious due to the presence of an extreme outlier. Removal of this outlier showed this correlation was not statistically significant.

\section{DISCUSSION}

Analyses of the disease and production data held on various marine farmed salmon sites located throughout Ireland between 1989 and 1994 indicated that PD was the major factor affecting profitable production during the majority of this time period. The high prevalence of PD, normally occurring at over $70 \%$ of marine sites,
Fig. 3. Regression relationship between the mortality rate from an outbreak of pancreas disease (PD) and the time of year at which the outbreak started

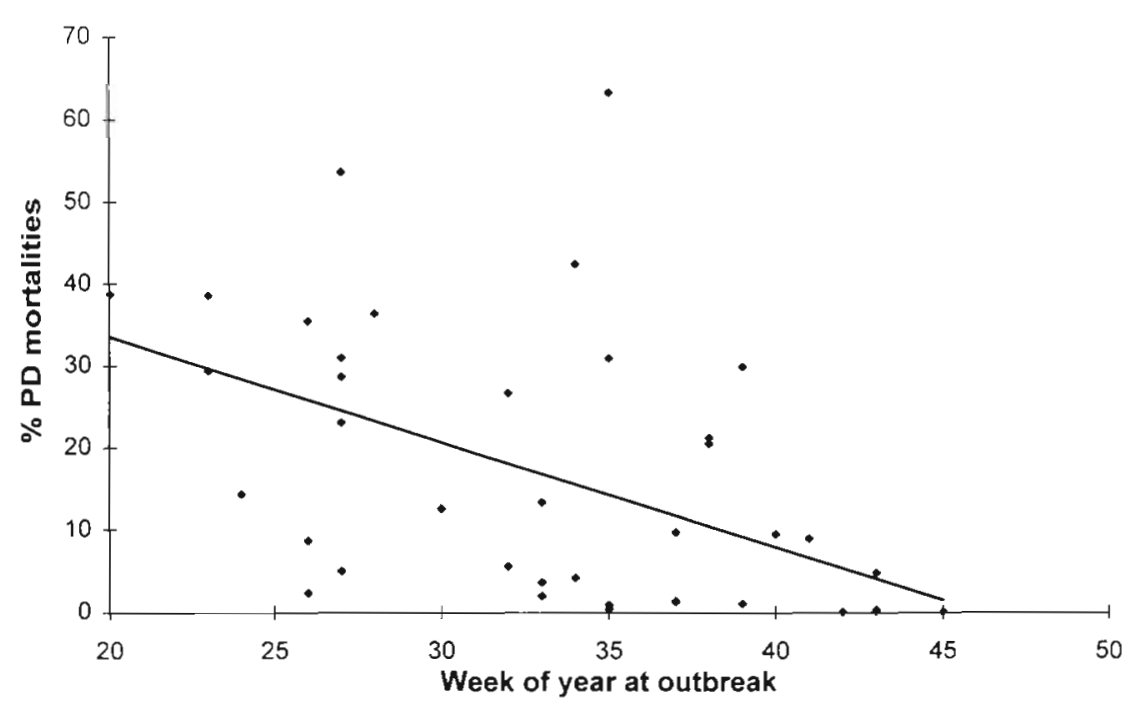


indicated the ubiquitous nature of the problem and the fact that the disease still remains a major impediment to the development of the Irish farmed salmon industry despite the downward trend in mortalities from the condition.

The significant differences in PD mortality rates between sites rather than between years demonstrated the importance of site management factors in decreasing losses and improving disease control. The site management factors which significantly reduced production losses were fallowing of the site for at least 3 wk before smolt input, single generation rearing on the site, slaughtering of fish away from the site and avoidance of farm staff movement between farm sites (Wheatley et al. 1995). These site management factors were associated with a significant reduction in total mortalities and only tended towards statistical significance when they were compared specifically with PDassociated mortalities. The lack of association between reduced PD mortalities and the aforementioned site management practices was probably due in part to a lack of data points to enable a difference to be demonstrable.

Since 1992, the majority of marine sites now practice single generation rearing (35\% pre-1993, $94 \%$ in 1993 and 1994) and fallowing of sites (26\% pre-1993, $94 \%$ in 1993 and 1994), which may have contributed to the significant reduction in mortality during 1993 to 1994 $(13.6 \%)$ compared to mortality rates in the previous 5 yr $(27.6 \%)$ (T. Crockford unpubl, data).

The tendency for PD outbreaks to occur during the August to October period is difficult to explain but could be due to the interaction of various determinants within the salmon and their environment. It would be tempting to postulate a possible link between PD outbreaks and high water temperature but unpublished findings would tend to err away from such a hypothesis. Namely, it is known that SPDV grows best at 12 to $14^{\circ} \mathrm{C}$ and less well at higher temperatures in vitro (M. F. McLoughlin unpubl. data). Perhaps this could be transferred to the natural infection situation with SPDV not surviving particularly well in relatively warm water temperatures. Interestingly, in 1995 when summer water temperatures were very high in Ireland, no PD occurred during the summer months with outbreaks occurring later in the year (McLoughlin et al. 1998). Additionally, no statistical relationship has been found between water temperature and PD outbreaks (T. Crockford unpubl. data). The lack of control sites where PD outbreaks has not occurred limited the investigations that can be carried out on environmental influences on PD outbreaks. Additionally, during this study period, smolts were placed in the marine sites within relatively short time intervals and were of relatively standard average weight so that any influ- ence on PD outbreaks resulting from host factors were largely negated.

Higher mortality rates were found when PD outbreaks occurred earlier in the smolt year and hence when the time interval from input to the PD outbreak was relatively short. This finding coincided with the fact that PD outbreaks lasted for longer time periods when they occurred earlier in the year. One explanation for these findings could be that virus concentrations were higher earlier in the year, resulting in an increased virus load infecting younger salmon populations which led to higher mortality rates. This hypothesis would tend to be supported with laboratory observations indicating that SPDV does not survive in relatively high summer water temperatures (M.F. McLoughlin unpubl. data). Many other fish viruses do not grow or survive when the environmental temperature rises above $15^{\circ} \mathrm{C}$ (Wolf 1988). Another explanation may be that non-specific immune responses may be more developed in older fish, hence, younger fish populations are more susceptible to the effects of PD. The higher mortality rates in PD outbreaks occurring earlier in the production cycle should not be considered as indicating a higher financial loss, as within this analysis no account was taken of the effect on overall biomass.

Sites 4 and 6, which were situated in the western and southern regions of Ireland respectively, showed consistently higher PD mortality rates over the years that were studied. Qualitative assessment of the information indicated no obvious differences between management practices on these sites compared to the other 4 sites that encountered a lower PD mortality rate.

Smolt input weight, initial stocking density and the level of transfer mortalities appear to have no effect on the occurrence of, or the mortality rate, due to PD outbreaks. Again, this may be partly a reflection of the large variation in some of the parameters. Similarly, no correlation was found between PD mortalities and losses from vibriosis.

The large dataset which has been collected over a number of production years has enabled the first quantitative description of the epidemiology of PD within the Irish farmed salmon industry. The information held within the database forms a substantial representative sample of the industry within Ireland, the generic nature of which will facilitate further analysis and development to meet the future needs of salmon producers

Acknowledgements. The authors wish to thank the Irish Salmon Growers' Association, an Bord Iascaigh Mhara, and The Marine Institute for part-funding this project. We are also grateful to the salmon producers who willingly supplied the information requested 


\section{LITERATURE CITED}

Anonymous (1998) A marine research, technology, development and innovation strategy for Ireland. A national team approach. The Marine Institute, Dublin

Bord Iascaigh Mhara (1987) The Atlantic salmon farming industry: past performance and future potential. BIM, Dun Laoghaire

Crockford T, McLoughlin MF, Menzies FD, Goodall EA, Wheatley SB (1998) Epidemiological investigations of disease in farmed Atlantic salmon (Salmo salar) in Ireland. Society for Veterinary Epidemiology and Preventive Medicine, Ennis, Co. Clare, p 161-169, March 1998

Draper NR, Smith H (1966) Applied regression analysis. Wiley, New York

Ellis AE (1987) Research in fish diseases. In: Baily RS, Parrish BB (eds) Developments in fisheries research in Scotland. Fishing News Books Ltd, Farnham, p 264-274

Ferguson HW, Roberts RJ, Richards RH, Collins RO, Rice DA (1986) Severe degenerative cardiomyopathy associated with pancreas disease. J Fish Dis 20:95-98

Houghton G (1994) Acquired protection in Atlantic salmon Salmo salar parr and post-smolts against pancreas disease. Dis Aquat Org 18:109-118

Jarp J (1998) Experience with the use of aquatic epidemiology in Norway. Society for Veterinary Epidemiology and Preventive Medicine, Ennis, Co. Clare, p 161-169, March 1998

Jarp J, Tangen $\mathrm{K}$, Willumsen FV, Djupvik HO, Tveit AM (1993) Risk factors for infection with Aeromonas salmonicida subsp. salmonicida in Norwegian freshwater hatcheries. Dis Aquat Org 17:81-86

Jarp J, Gjevre AG, Olsen AB, Bruhiem T (1994) Risk factors for furunculosis and infectious pancreatic necrosis and mortality in post-smolt of Atlantic salmon. J Fish Dis 18:67-78

Kent ML, Elston RA (1987) Pancreas disease in pen-reared Atlantic salmon in North America. Bull Eur Assoc Fish Pathol 7:29-31

McLoughlin MF, Nelson RT, Rowley HM, Cox DI, Grant AN (1996) Experimental pancreas disease in Atlantic salmon Salmo salar post-smolts induced by salmon pancreas disease virus (SPDV). Dis Aquat Org 26:117-124

McLoughlin MF, Rowley HM, Doherty CE (1998) A serologi-

Editorial responsibility: Jo-Ann Leong,

Corvallis, Oregon, USA cal survey of salmon pancreas disease virus (SPDV) antibodies in farmed Atlantic salmon (Salmo salar L.). J Fish Dis 21:305-307

McVicar AH (1987) Pancreas disease in farmed Atlantic salmon, Salmo salar, in Scotland: epidemiology and early pathology. Aquaculture 67:71-78

McVicar AH (1990) Infection as a primary cause of pancreas disease in farmed Atlantic salmon. Bull Eur Assoc Fish Pathol 10:84-87

Menzies FD, Wheatley SB, Goodall EA, McLoughlin MF (1996) Development of a computerized information retrieval system for Atlantic salmon, Salmo salar L., production. Aquacult Res 27:183-190

Munro ALS, Ellis EA, McVicar AH, McLay HA, Needham EA (1984) An exocrine pancreas disease of farmed Atlantic salmon in Scotland. Helgol Meeresunters 37:571-586

Murphy TM, Rodger HD, Drinan EM, Gannon F, Kruse P, Körting W (1992) The sequential pathology of pancreas disease in Atlantic salmon farms in Ireland. J Fish Dis 15: 401-408

Nelson RT, McLoughlin MF, Rowley HM, Platten MA, McCormick JI (1995) The isolation of a toga-like virus from farmed Atlantic salmon Salmo salar with pancreas disease. Dis Aquat Org 22:25-32

Poppe T, Rimstad E, Hyllseth B (1989) Pancreas disease in Atlantic salmon (Salmo salar) postsmolts infected with infectious pancreatic necrosis virus (IPNV). Bull Eur Assoc Fish Pathol 9:83-85

Raynard RS, Houghton G (1993) Development towards an experimental protocol for the transmission of pancreas disease of Atlantic salmon Salmo salar. Dis Aquat Org 15: $123-128$

Raynard RS, Houghton, G (1995) Comparative experimental transmission of pancreas disease in Atlantic salmon, rainbow trout and brown trout. Dis Aquat Org 22:19-24

Walters DE (1979) In defence of the arc sine approximation. The Statistican 28:219-223

Wheatley SB, McLoughlin MF, Menzies FD, Goodall EA. (1995) Site management factors influencing mortality rates in Atlantic salmon (Salmo salar L.) during marine production. Aquaculture 136:195-207

Wolf K (1988) Fish viruses and fish viral diseases. Cornell University Press, Ithaca, NY

Submitted: June 26, 1998; Accepted: January 20, 1999

Proofs received from author(s): May 3, 1999 